\title{
Pengaruh Financing to Deposit Ratio, Capital Adequacy Ratio dan Non Performing Financing terhadap Profitabilitas pada Bank Umum Syariah
}

\author{
Muhammad Rivandi $^{1^{*}}$,Tania Gusmariza ${ }^{2)}$ \\ Sekolah Tinggi Ilmu Ekonomi KBP ${ }^{1,2}$ \\ muhammadrivandi@akbpstie.ac.id ${ }^{1}$, gusmarizatania@gmail.com ${ }^{2}$
}

*Penulis Koresponden

Diajukan : 14 Juni 2021

Disetujui : : 12 Juli 2021

Dipublikasi : 1 Agustus 2021

\begin{abstract}
Probability is the ability of a Company to generate profits for a certain period. Profitability shows the ratio of profit to assets or capital that creates profit. Bank Indonesia prioritizes the profitability of a bank which is measured by assets whose funds mostly come from public savings funds so that ROA is considered more representative in measuring banking profitability. This study aims to examine The effect of Financing to Deposit ratio, Capital Adequacy Ratio and Non Performing Financing on profitability. The population of this study is all Islamic commercial banking companies in Indonesia from 2017 to 2019, with the selection of a sample of companies using porposive sampling, so that the number of samples that match the criteria are eleven companies. The data analysis method used in this study is a panel regression model. Based on the results of hypothesis testing, that the Financing to Deposit Ratio and Non Performing Financing has no effect on profitability, while the Capital Adequacy Ratio has a positive and significant effect on profitability.
\end{abstract}

Keywords: Capital Adequacy Ratio, Financing to Deposit ratio, , Non Performing Financing, Profitability.

\section{PENDAHULUAN}

Ekonomi digital memasusi era baru yang disebut revolusi 4.0. menipisnya batas antar dunia maya dan dunia nyata mempengaruhi kehidupan salah satunya perbankan penetapan lingkungan yang efektif dan aman agar berhasil dan mapu mentransformasukan semua sektor terutama sektor ekonomi dan bisnis. Perbankan syariah di Indonesia dalam 10 tahun terakhir sanagt signifikan baik dilihat dari aspek kelembagaan, maupun dare perkembangan aset, dana pihak ketiga maupun dare sisi pembiayaan. Perkembangan perbankan syariah akan tetap tumbuh secara lebih baik mengingat kesadaran masyarakat untuk bertransaksi sesuai syariah (Hidayat \& Meiranto, 2018). Situasi ini membuat industri perbankan syariah dituntut untuk memiliki kinerja yang baik agar dapat bersaing dalam memperebutkan pangsa pasar perbankan syariah di Indonesia (Hanafiah \& Sari, 2016).

Prasetiono (2016) menjelaskan bahwa bank yang dapat menghimpun dana dan menyalurkannya kembali dengan optimal akan memberikan efek positif bagi bank itu sendiri karena dengan mengoptimalkan modal yang dimiliki akan memungkinkan bank untuk mendapatkan keuntungan sesuai dengan yang diharapkan. Keuntungan yang diharapkan bank tentunya menjadi salah satu tujuan, baik dari pihak manajemen ataupun investor yang menyimpan modalnya, dengan mendapatkan keuntungan sesuai dengan apa yang sudah diatur sebelumnya sehingga mampu meningkatkan mutu produk, melakukan investasi baru, serta kesejahteraan karyawan dan pemilik perusahaan. Keuntungan yang besar dapat menjadi suatu indikator keberhasilan bank dalam menjalankan usahanya. Keuntungan tersebut dapat dilihat dari profitabilitas suatu bank. 
Indikator dari kinerja suatu perusahaan salah satunya adalah profitabilitas. Menurut (Prabowo \& Sutanto, 2019) profitabilitas merupakan kemampuan manajemen dalam menghasilkan laba. Salah satu proksi yang tepat untuk mengukur profitabilitas suatu bank adalah dengan melihat besar kecilnya Return On Asset. Return On Asset (ROA) menunjukkan kemampuan bank dalam menghasilkan income dari pengelolaan aset yang dimilikinya. Semakin besar Return On Asset (ROA) suatu bank maka semakin besar tingkat keuntungan yang dicapai bank tersebut dan semakin baik pula posisi bank tersebut dari segi penggunaan aset.

Profitabilitas yaitu suatu kemampuan perusahaan agar menghasilkan laba pada periode tertentu. Profitabilitas memperlihatkan perbandingan laba dengan aktiva ataupun modal yang menciptakan laba. Profitabilitas menggambarkan kemampuan perusahaan dalam mendapatkan laba melalui seluruh kemampuan, serta sumber yang tersedia seperti kas, modal, kegiatan penjualan, jumlah karyawan, serta jumlah cabang dan lainnya (Marlina \& Rivandi, 2020), (Rivandi, 2020; Rivandi \& Septiano, 2021)

Profitabilitas dapat dikatakan sebagai salah satu indikator yang paling tepat untuk mengukur kinerja suatu perusahaan. Rasio yang biasanya digunakan untuk mengukur kinerja profitabilitas adalah Return on Asset (ROA), dan Return on Equity (ROE). Latar belakang dipilihnya ROA sebagai ukuran kinerja adalah karena ROA digunakan untuk mengukur kemampuan manajemen bank guna memperoleh keuntungan secara keseluruhan. Dalam menentukan kinerja atau kesehatan perbankan, Bank Indonesia (BI) lebih merujuk ROA dari pada ROE. BI lebih mengutamakan profitabilitas suatu bank yang di ukur dengan aset yang dananya sebagian besar berasal dari dana simpanan masyarakat sehingga ROA dinilai lebih mewakili dalam pengukuran profitabilitas perbankan (Prabowo \& Sutanto, 2019).

Rasio profitabilitas adalah perbandingan laba (setelah pajak) dengan modal atau laba (sebelum pajak) dengan total aset yang dimiliki perusahaan pada periode tertentu agar hasil perhitungan rasio mendekati pada kondisi yang sebenarnya itu sebabnya posisi modal dihitung secara rata-rata selama periode tersebut. Rasio profitabilitas ini menunjukkan tingkat efektivitas yang dicapai melalui usaha operasional perusahaan, konsep ini sering digunakan sebagai indikator kinerja fundamental perusahaan untuk mewakili kinerja manajemen dan apabila kinerja manajemen perusahaan yang diukur menggunakan dimensi-dimensi profitabilitas dalam kondisi baik, maka akan memberikan dampak positif terhadap keputusan investor untuk menanamkan modalnya (Prabowo \& Sutanto, 2019).

Rujukan pada penelitian ini ialah penelitian yang dilakukan oleh Almunawwaroh \& Marliana (2018) dan Aldiansyah (2018) yang meneliti Financing to Deposit Ratio, Capital Adequacy Ratio dan Non Performing Financing Terhadap Profitabilitas pada Perusahaan Bank Umum Syariah di Indonesia Periode 2015-2019. Penelitian yang dilakukan peneliti mempunyai perbedaan dengan penelitian sebelumnya, perbedaan tersebut seperti variabel independen yang peneliti angkatkan berbeda dengan variabel independen penelitian sebelumnya dan objek penelitian yang peneliti pakai ialah pada perusahaan Bank Umum Syariah di Indonesia Periode 2017-2019. Peneliti memilih perusahaan bank umum syariah untuk dijadikan objek pada penelitian ini karena menurut peneliti perusahaan perbankan ialah salah satu perusahaan yang diminati oleh para investor untuk berinvestasi, karena sektor tersebut memiliki potensi pertumbuhan dan menghasilkan laba ke depan yang cukup bagus seiring dengan pertumbuhan ekonomi Indonesia saat ini yang meningkat, sebab itulah peneliti tertarik mengambil objek penelitian perusahaan bank umum syariah di Indonesia.

\section{STUDI LITERATUR \\ Pengaruh Financing to Deposit Ratio Terhadap Profitabilitas}

FDR (Financing to Deposit Ratio) adalah perbandingan antara pembiayaan yang diberikan oleh bank dengan dana pihak ketiga (DPK) yang berhasil dikerahkan oleh bank. FDR tersebut menyatakan seberapa jauh kemampuan bank dalam membayar kembali penarikan dana yang dilakukan deposan dengan mengandalkan kredit yang diberikan sebagai sumber likuiditasnya. Pemberian kredit kepada nasabah kredit dapat mengimbangi kewajiban bank untuk segera memenuhi permintaan deposan yang ingin menarik kembali uangnya yang telah digunakan oleh bank untuk memberikan kredit. (Yusuf, 2017). 
Penelitian yang dilakukan Syakhrun (2019), Almunawwaroh \& Marliana (2018) dan Yusuf (2017) menunjukkan hasil berpengaruh positif dan signifikan terhadap profitabilitas. Semakin tinggi rasio FDR maka akan mencerminkan bahwa semakin efektif suatu bank dalam menyalurkan pembiayaannya dengan asumsi bahwa rasio ini berada dalam batas yang ditetapkan oleh Bank Indonesia. Semakin besar pembiayaan maka pendapatan yang diperoleh juga akan naik, karena pendapatan naik secara otomatis laba juga akan mengalami kenaikan, dengan kata lain seberapa jauh pemberian pembiayaan kepada nasabah dapat mengimbangi kewajiban bank untuk segera memenuhi permintaan deposan untuk menarik kembali uangnya yang telah digunakan oleh bank untuk memberikan pembiayaan. Berdasarkan atas teori dan hasil penelitian terdahulu maka peneliti merumuskan hipotesis yang akan dibuktikan secara empiris yaitu:

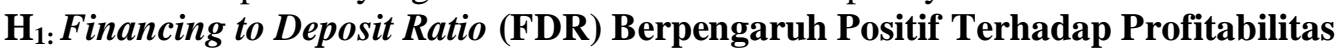

\section{Pengaruh Capital Adequacy Ratio Terhadap Profitabilitas}

Capital Adequacy Ratio (CAR) merupakan rasio antara modal sendiri terhadap Aktiva Tertimbang Menurut Risiko (ATMR). Capital Adequancy Ratio (CAR) adalah rasio yang memperlihatkan seberapa besar jumlah seluruh aktiva bank yang mengandung unsur risiko (kredit, penyertaan, surat berharga, tagihan pada bank lain) yang ikut dibiayai dari modal sendiri di samping memperoleh dana-dana dari sumber-sumber di luar bank, dengan kata lain Capital Adequacy Ratio adalah rasio kinerja bank untuk mengukur kecukupan modal yang dimiliki bank untuk menunjang aktiva yang mengandung atau menghasilkan risiko (Pinasti \& Mustikawati, 2018).

Penelitian yang dilakukan Yusuf (2017), Khoirunnisa et al (2016).dan Hanafia \& Karim (2020).menunjukkan bahwa Capital Adequacy Ratio (CAR) berpengaruh positif terhadap profitabilitas. Peningkatan profitabilitas turut diikuti pula oleh meningkatnya kebutuhan pembentukan cadangan dalam rangka mengantisipasi konsekuensi peningkatan risiko sejalan dengan optimalisasi produktivitas aset, sehingga kecukupan permodalan yang diproksikan dengan CAR mengalami penurunan. Kenaikan CAR akan mengakibatkan kenaikan pada profitabilitas yang menunjukkan bahwa modal bank cukup/mampu membiayai kegiatan usahanya. CAR yang tinggi menunjukkan bank mempunyai kecukupan modal yang tinggi, dengan modal yang tinggi bank dapat leluasa untuk menetapkan dananya ke dalam investasi yang menguntungkan, hal tersebut mampu meningkatkan kepercayaan nasabah karena kemungkinan bank memperoleh laba sangat tinggi dan kemungkinan bank terlikuiditas kecil. Berdasarkan teori dan hasil penelitian maka peneliti merumuskan hipotesis yang akan dibuktikan secara empiris yaitu:

\section{$\mathrm{H}_{2:}$ Capital Adequacy Ratio (CAR) Berpengaruh Positif Terhadap Profitabilitas}

\section{Pengaruh Non Performing Financing Terhadap Profitabilitas}

Non Performing Financing (NPF) merupakan rasio yang dipergunakan untuk mengukur risiko terhadap kredit yang disalurkan dengan membandingkan kredit macet dengan jumlah kredit yang disalurkan. NPF adalah rasio yang digunakan untuk mengetahui pembiayaan bermasalah yang ditanggung oleh perbankan berdasarkan total pembiayaan yang telah disalurkan perbankan. Semakin tinggi NPF maka semakin kecil pula perubahan labanya, hal ini dikarenakan pendapatan yang diterima bank akan berkurang dan biaya untuk pencadangan penghapusan piutang akan bertambah yang mengakibatkan laba menjadi menurun atau rugi menjadi naik. NPF erat kaitannya dengan pembiayaan yang disalurkan oleh bank syariah kepada nasabahnya (Munir, 2018).

Penelitian yang dilakukan Izzah et al., (2019), Prasetiono (2016).dan (Munir, 2018) menunjukkan bahwa Non Performing Financing (NPF) berpengaruh positif terhadap profitabilitas. semakin tinggi nilai NPF bank umum syariah mengakibatkan semakin tinggi ROA bank tersebut. Laba perbankan dapat meningkat dengan NPF yang tinggi karena sumber laba selain dari bunga seperti fee based income yang relatif tinggi. Selain itu NPF bisa terjadi bukan karena debitur tidak sanggup membayar akan tetapi ketatnya peraturan Bank Indonesia dalam hal penggolongan kredit yang mengakibatkan debitur yang tadinya berada dalam kategori lancar bisa turun Berdasarkan teori dan hasil penelitian maka peneliti merumuskan hipotesis yang akan dibuktikan secara empiris yaitu:

\section{$\mathrm{H}_{\text {3: Non Performing Financing (NPF) Berpengaruh Positif Terhadap Profitabilitas }}$}




\section{Data dan Sampel}

\section{METODE}

Penelitian ini menggunakan metode penelitian kuantitatif. Jenis data yang gunakan dalam penelitian ini adalah data panel. Data panel adalah gabungan data time series dengan data cross section. Di dalam ilmu ekonomi, penggunaan data analisis terhadap daerah atau perusahaan dalam periode waktu tertentu. Analisis dengan data panel memberikan informasi yang lebih lengkap (Purwanto \& Sulistyatuti, 2017).

Sumber data yang digunakan dalam penelitian ini adalah data sekunder. Data ini bersumber dari Laporan Keuangan Tahunan (Annual Report) perusahaan bank umum syariah di Indonesia tahun 2017-2019 yang diambil dari website perusahaan bank umum syariah di Indonesia. Populasi dari penelitian ini merupakan seluruh perusahaan bank umum syariah di Indonesia tahun 2017 sampai tahun 2019. Teknik pengambilan sampel dalam penelitian ini menggunakan metode Purposive Sampling. Menurut (Sugiyono, 2017) teknik purposive sampling yaitu teknik penentuan sampel dengan menggunakan pertimbangan tertentu. Adapun kualifikasi dalam pemilihan sampel sebagai berikut: (1) Perusahaan Bank Umum Syariah di Indonesia dari tahun 2017- 2019 (2) Perusahaan Bank Umum Syariah di Indonesia yang tidak memiliki laporan keuangan lengkap pada tahun 2017-2019 (3) Perusahaan Bank Umum Syariah di Indonesia yang mengalami kerugian selama periode 2017-2019. Berdasarkan kriteria sampling tersebut diketahui jika jumlah perusahaan sampel yang digunakan ialah 11 Perusahaan Bank Umum Syariah di Indonesia dengan tahun penelitian selama 3 tahun (2017-2019) dan jumlah data akhir yang digunakan pada penelitian ini ialah 33 data observasi.

\section{Definisi Operasional Variabel}

\section{Tabel 1 Definisi Operasional}

\begin{tabular}{|c|c|c|c|c|}
\hline No & Variabel & Pengertian & Pengukuran & Sumber \\
\hline 1 & $\begin{array}{l}\text { Profitabilita } \\
\text { s } \\
\text { (Y) }\end{array}$ & $\begin{array}{l}\text { kemampuan manajemen } \\
\text { dalam menghasilkan laba. } \\
\text { Salah satu proksi yang } \\
\text { tepat untuk mengukur } \\
\text { profitabilitas suatu bank } \\
\text { adalah dengan melihat } \\
\text { besar kecilnya Return On } \\
\text { Asset. }\end{array}$ & $\begin{array}{l}\mathrm{ROA}= \\
\frac{\text { Laba Setelah Pajak }}{\text { Total Aktiva }}\end{array}$ & $\begin{array}{l}\text { Almunawwar } \\
\text { oh \& Marliana } \\
(2018)\end{array}$ \\
\hline 2 & $\begin{array}{l}\text { Financial } \\
\text { to Deposit } \\
\text { Ratio }\left(\mathrm{X}_{1}\right)\end{array}$ & $\begin{array}{lr}\text { Perbandingan antara } \\
\text { pembiayaan } \\
\text { diberikan oleh bank } \\
\text { dengan dana pihak ketiga } \\
\text { (DPK) yang berhasil } \\
\text { dikerahkan oleh bank. }\end{array}$ & $\begin{array}{l}\mathrm{FDR}= \\
\frac{\text { Total Pembiayaan }}{\text { Total DPK }}\end{array}$ & Yusuf (2017) \\
\hline 3 & $\begin{array}{l}\text { Capital } \\
\text { Adequacy } \\
\text { Ratio } \\
\left(\mathrm{X}_{2}\right)\end{array}$ & $\begin{array}{l}\text { Kecukupan modal yang } \\
\text { menunjukkan kemampuan } \\
\text { bank dalam } \\
\text { mempertahankan modal } \\
\text { yang mencukupi dan } \\
\text { kemampuan manajemen } \\
\text { bank dalam } \\
\text { mengidentifikasi, } \\
\text { mengukur, mengawasi, } \\
\text { dan mengontrol risiko- } \\
\text { risiko yang timbul yang } \\
\text { dapat berpengaruh } \\
\text { terhadap besarnya modal. }\end{array}$ & CAR $\frac{\text { Modal Bank }}{\text { Total ATMR }} \times 100 \%$ & $\begin{array}{l}\frac{\text { Almunawwar }}{\text { oh \& Marliana }} \\
\underline{(2018)}\end{array}$ \\
\hline
\end{tabular}


Owner: Riset \& Jurnal Akuntansi

e-ISSN : 2548-9224 |p-ISSN : 2548-7507

Volume 5 Nomor 2, Agustus 2021

\begin{tabular}{|c|c|c|c|c|}
\hline No & Variabel & Pengertian & Pengukuran & Sumber \\
\hline 4 & $\begin{array}{l}\text { Non } \\
\text { Performing } \\
\text { Financing } \\
\left(\mathrm{X}_{3}\right)\end{array}$ & $\begin{array}{l}\text { Rasio yang digunakan } \\
\text { untuk mengetahui } \\
\text { pembiayaan bermasalah } \\
\text { yang ditanggung oleh } \\
\text { perbankan berdasarkan } \\
\text { total pembiayaan yang } \\
\text { telah disalurkan } \\
\text { perbankan. }\end{array}$ & $\begin{array}{l}\text { NPF Net }= \\
\frac{\text { Pembiayaan }}{\text { Total Financing }}\end{array}$ & Munir, (2018) \\
\hline
\end{tabular}

\section{Teknik Analisis Data}

\section{Model Regresi Berganda}

Teknik analisis data pada penelitian ini dapat dipakai regresi data panel dengan menggunakan software pengolah data statistik Eviews 8 untuk melakukan pengujian.

Bentuk model regresi data panel yang dipakai ialah:

$$
\mathbf{Y}_{\text {it }}=\mathbf{a}+\boldsymbol{\beta} 1 \mathbf{X}_{\mathrm{FDRit}}+\boldsymbol{\beta 2} \mathbf{X}_{\mathrm{CARit}}+\boldsymbol{\beta 3} \mathbf{X}_{\mathrm{NPFit}}
$$

Keterangan $: \mathrm{Y}_{\mathrm{it}}=$ Variabel Terikat (Profitabilitas), $\mathrm{a}=$ Konstanta, $\mathrm{X}_{\mathrm{FDRit}}=$ Financial to Deposit Ratio (FDR), $\mathrm{X}_{\mathrm{CARit}}=$ Capital Adequacy Ratio $(\mathrm{CAR}), \mathrm{X}_{\mathrm{NPFit}}=$ Non Performing Financing (NPF), $\beta 1-\beta 3=$ koefisien variabel

\section{Uji Hipotesis}

\section{Uji t (Uji Koefisien Regresi)}

Menurut Mansuri (2016), uji t digunakan untuk menguji konstanta yang diduga untuk mengestimasi persamaan dapat menjelaskan pengaruh variabel dependen terhadap variabel independen. Inti pengambilan pada keputusan digunakan dalam uji t ialah jika nilai dari probabilitas signifikansi lebih besar $>0,05$, maka hipotesis tersebut dapat ditolak tetapi jika pada nilai probabilitas signifikansi lebih kecil $<0,05$, maka hipotesis tersebut dapat diterima.

\section{Uji Pemilihan Model}

\section{HASIL}

\section{Uji Chow}

Uji Chow ini dilakukan dengan tujuan untuk memilih apakah penelitian ini menggunakan menggunakan common effect atau menggunakan fixed effect. Berikut adalah hasil dari Uji Chow dan keputusan yang diambil berdasarkan Uji Chow dengan pengolahan data Eviews versi 8

Tabel 4 Hasil Uji Chow

\begin{tabular}{|l|l|l|l|}
\hline Redundant Fixed Effects Tests & & \\
\hline Equation: Untitled & & \\
\hline Test cross-section fixed effects \\
\hline Effects Test & Statistic & d.f. & Prob. \\
\hline Cross-section F & 124.458574 & $(10,19)$ & 0.0000 \\
\hline Cross-section Chi-square & 138.509904 & 10 & 0.0000 \\
\hline
\end{tabular}

Sumber: Pengolahan Data Eviews 8, 2021

Berdasarkan tabel 4 diatas, diperoleh nilai probability untuk cross section Chi-Square sebesar $0,0000<0,005$ sehingga hasil menunjukkan bahwa $\mathrm{H}_{0}$ ditolak dan $\mathrm{H}_{1}$ diterima, artinya model fixed effect lebih tepat digunakan dari pada common effect untuk mengestimasi data panel. Proses selanjutnya harus melalui uji Haussman.

\section{Hasil Uji Haussman}

Setelah tahapan pengujian signifikansi model fixed effect lebih baik digunakan pada penelitian ini daripada common effect. Lalu diujikan kembali pada model panel fixed effect atau random effect yang lebih sesuai, untuk menentukan hal tersebut dilakukan Uji Haussman, sedangkan untuk hipotesis, hasil dan keputusan dari Uji Hausman adalah sebagai berikut: 
Tabel 5 Hasil Uji Haussman

\begin{tabular}{|l}
\hline Correlated Random Effects - Hausman Test \\
\begin{tabular}{|l|l|l|l|}
\hline Equation: Untitled \\
\hline Test cross-section random effects \\
\hline \multicolumn{3}{|l|}{ Chi-Sq. } \\
Test Summary & Statistic & Chi-Sq. d.f. & Prob. \\
\hline Cross-section random & 5.161752 & 3 & 0.1603 \\
\hline
\end{tabular}
\end{tabular}

Sumber: Pengolahan Data Eviews 8, 2021

Berdasarkan table 5 di atas, diperoleh nilai probability untuk cross-section random sebesar $0,1603>0,005$ sehingga hasil uji menunjukkan jika $\mathrm{H}_{0}$ diterima dan $\mathrm{H}_{1}$ ditolak, maka dapat disimpulkan model Random Effect layak untuk digunakan.

\section{Regresi Data Panel (Random Effect Model)}

Regresi data panel merupakan penelitian yang menggabungkan antara cross section (data silang) dengan time series (runtut waktu). Berdasarkan kedua pengujian sebelumnya maka peneliti menyimpulkan menggunakan uji haussman dengan pemilihan Random Effect Model (REM). Hal ini dikarenakan dengan menggunakan uji Haussman mendapati hasil dengan nilai signifikansi di atas 5\% sehingga dengan dasar tersebut peneliti memilih REM sebagai model yang tepat. Berikut ini adalah tampilan Random Effect Model (REM) yang didapatkan dengan menggunakan software Eviews 8.0.

Tabel 6 Hasil Uji Random Effect Model

\begin{tabular}{|l|l|l|l|l|}
\hline Variable & Coefficient & Std. Error & t-Statistic & Prob. \\
\hline C & 3.109256 & 2.133863 & 1.457102 & 0.1558 \\
\hline X1 & -0.028099 & 0.023913 & -1.175059 & 0.2495 \\
\hline X2 & 0.081545 & 0.022039 & 3.700070 & 0.0009 \\
\hline X3 & -0.190058 & 0.158002 & -1.202884 & 0.2388 \\
\hline
\end{tabular}

Sumber : Pengolahan Data Eviews 8, 2021

Berdasarkan persamaan regresi panel diatas, didapat persamaan sebagai berikut:

$$
\text { Yit }=3,109-0,028 \text { FDRit }+0,081_{\text {CARit }}-\mathbf{0 , 1 9 0} \text { NPFit }_{\text {}}
$$

Berdasarkan model persamaan regresi di atas dapat dijelakan sebagai berikut :

Hasil persamaan di atas diperoleh konstanta sebesar 3,109 yang artinya jika FDR, CAR dan NPF mengalami kenaikan sebesar $1 \%$ maka profitabilitas perusahaan bank umum syariah mengalami kenaikan sebesar 3,109 jik a FDR, CAR dan NPF dianggap tetap atau sama dengan 0 .

Koefisien regresi variabel Financing to Deposit Ratio (FDR) bernilai negatif sebesar 0,028 artinya apabila FDR mengalami kenaikan sebesar 1\%, maka profitabilitas perusahaan bank umum syariah akan mengalami penurunan sebesar 0,028 jika variabel independen lain nilainya tetap atau konstan.

Koefisien regresi Capital Adequacy Ratio (CAR) bernilai positif sebesar 0,081 artinya apabila CAR mengalami kenaikan sebesar 1\%, maka profitabilitas perusahaan bank umum syariah akan mengalami kenaikan sebesar 0,081 jika variabel independen lain nilainya tetap atau konstan.

Koefisien regresi Non Performing Financing (NPF) bernilai negatif sebesar 0,190 artinya apabila NPF mengalami kenaikan 1\%, maka profitabilitas perusahaan bank umum syariah akan mengalami penurunan sebesar 0,190 jika variabel independen lain nilainya tetap atau konstan.

\section{Uji Asumsi Klasik}

\section{Uji Normalitas}

Uji normalitas bertujuan untuk menguji apakah dalam model regresi, variabel pengganggu atau residual memiliki distribusi normal. Uji statistik yang digunakan dalam penelitian ini adalah Jarque-Bera Test. Kriteria yang diambil adalah Apabila nilai probabilitasnya lebih besar dari 
0,05 maka data berdistribusi normal, begitu sebaliknya jika nilai probabilitasnya kecil dari 0,05 maka data berdistribusi tidak normal. Berikut hasil pengolahan statistik pada uji normalitas :

Tabel 7 Uji Normalitas

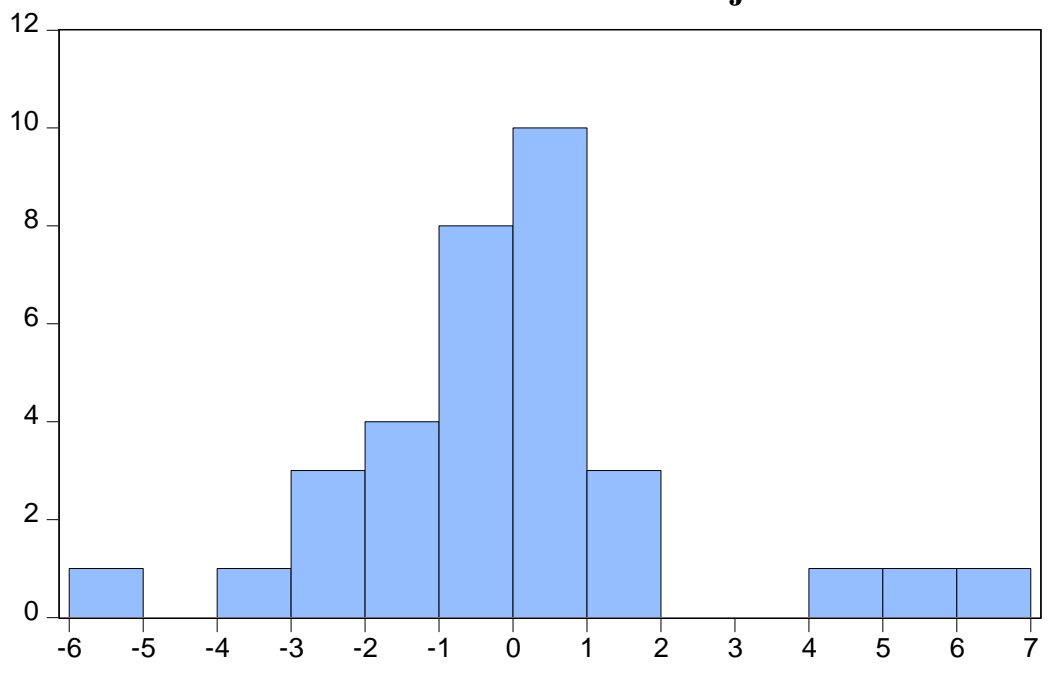

Series: Standardized Residuals Sample 20172019

Observations 33

Mean $\quad 1.53 e-15$

Median $\quad-0.008009$

Maximum $\quad 6.372241$

Minimum $\quad-5.483863$

Std. Dev. 2.335583

Skewness 0.650931

Kurtosis $\quad 4.561880$

Jarque-Bera $\quad 5.684677$

Probability 0.058289

sumber: Pengolahan Eviews 82021

Hasil analisis metode Jarque-Bera menunjukkan bahwa nilai probability diperoleh sebesar 0,058 dengan tingkat signifikansi yang digunakan 0,05 maka diperoleh hasil 0,058>0,05, dengan demikian pengujian normalitas ini diterima karena data berdistribusi normal. Berdasarkan hasil tersebut dapat disimpulkan bahwa variabel Financing to Deposit Ratio, Capital Adequacy Ratio dan Non Performing Financing telah terdistribusi secara normal.

\section{Uji Hipotesis}

\section{Uji T}

Uji statistik t pada dasarnya menunjukkan seberapa jauh pengaruh satu variabel individu independen secara individu dalam menerangkan variabel dependen, jika nilai probabilitas lebih kecil daripada 0,05 untuk tingkat signifikansi 5\%, maka variabel independen secara satu persatu berpengaruh terhadap variabel dependen sehingga $\mathrm{H}_{0}$ ditolak dan $\mathrm{H}_{1}$ diterima, sedangkan jika nilai probabilitas lebih besar dari pada 0,05 maka variabel independen secara satu persatu tidak berpengaruh terhadap variabel dependen, yang berarti $\mathrm{H}_{0}$ di terima dan $\mathrm{H}_{1}$ ditolak. Uji hipotesis secara parsial dapat dilihat dari tabel berikut:

Tabel 8 Hasil Uji T

\begin{tabular}{|l|l|l|l|l|l|}
\hline Variable & Coeffisient & Std.Error & t-Statistic & Prob & Keterangan \\
\hline C & 3,109256 & 2,133863 & 1,457102 & 0,1558 & \\
\hline X1 & $-0,028099$ & 0,023913 & $-1,175059$ & 0,2495 & $\mathrm{H}_{1}$ Ditolak \\
\hline X2 & 0,081545 & 0,022039 & 3,700070 & 0,0009 & $\mathrm{H}_{2}$ Diterima \\
\hline X3 & $-0,190058$ & 0,158002 & $-1,202884$ & 0,2388 & $\mathrm{H}_{3}$ Ditolak \\
\hline
\end{tabular}

Sumber : Pengolahan Data Eviews 8, 2021

Hasil pengujian dengan analisis regresi data panel pada table 8 menunjukkan nilai coefficient FDR sebesar - 0,028 menunjukkan bahwa arah koefisien negatif, sedangkan probabilitas FDR sebesar 0,2495 > 0,05 sehingga $\mathrm{H}_{0}$ diterima dan $\mathrm{H}_{1}$ ditolak, maka dapat disimpulkan bahwa Financing to Deposit Ratio tidak memiliki pengaruh terhadap profitabilitas pada Perusahaan Bank Umum Syariah di Indonesia Periode 2017-2019. 
Hasil pengujian dengan analisis regresi data panel pada tabel 8 menunjukkan nilai coefficient CAR sebesar 0,081 menunjukkan bahwa arah koefisien positif, sedangkan probabilitas CAR sebesar 0,0009 $<0,05$ sehingga $\mathrm{H}_{0}$ ditolak dan $\mathrm{H}_{2}$ diterima, maka dapat disimpulkan bahwa Capital Adequacy Ratio memiliki pengaruh positif dan signifikan terhadap profitabilitas pada Perusahaan Bank Umum Syariah di Indonesia Periode 2017-2019.

Hasil pengujian dengan analisis regresi data panel pada tabel 8 menunjukkan nilai coefficient NPF sebesar -0,190 menunjukkan bahwa arah koefisien negatif, sedangkan probabilitas NPF sebesar 0,2388 > 0,05 sehingga $\mathrm{H}_{0}$ diterima dan $\mathrm{H}_{3}$ ditolak, maka dapat disimpulkan bahwa Non Performing Financing tidak memiliki pengaruh terhadap profitabilitas pada Perusahaan Bank Umum Syariah di Indonesia Periode 2017-2019.

\section{PEMBAHASAN}

\section{Pengaruh Financing to Deposit Ratio (FDR) Terhadap Profitabilitas}

'Berdasarkan pengujian statistik yang telah dilakukan menunjukkan bahwa FDR tidak memiliki pengaruh terhadap Profitabilitas pada Perusahaan Bank Umum Syariah di Indonesia Periode 2017-2019. Setiap peningkatan atau penurunan FDR tidak akan mempengaruhi naik turunnya ROA. Hal ini menunjukkan bahwa bank akan tetap mendapatkan laba walaupun FDR yang dimiliki bank mengalami penurunan ataupun peningkatan. Hasil penelitian yang menunjukkan tidak signifikannya antara FDR dengan ROA, disebabkan oleh pembiayaan yang disalurkan oleh perusahaan perbankan syariah belum berjalan secara efektif dan optimal, sehingga menyebabkan pembiayaan non-lancar meningkat seiring dengan total pembiayaan yang disalurkan oleh perusahaan perbankan syariah, hal ini dapat terjadi sebab pihak manajemen bank kurang menerapkan prinsip kehati-hatian dalam menilai calon nasabah pembiayaan.

Penelitian ini mendukung penelitian yang dilakukan Munir (2018) dan Prasetiono (2016) yang menyatakan bahwa FDR tidak berpengaruh terhadap profitabilitas. Tinggi rendahnya nilai FDR yang diperoleh oleh Bank Umum Syariah tidak berpengaruh terhadap peningkatan Profitabilitas (ROA). Menurunnya nilai FDR pada bank syariah menunjukkan bahwa bank dalam menyalurkan pembiayaan sebagai sumber likuiditasnya belum dilakukan dengan baik, hal ini disebabkan pembiayaan yang disalurkan oleh pihak perbankan syariah belum berjalan dengan efektif dan optimal sehingga menyebabkan pembiayaan yang tidak lancar meningkat seiring dengan total pembiayaan yang dilakukan oleh pihak perbankan.

\section{Pengaruh Capital Adequacy Ratio (CAR) Terhadap Profitabilitas}

Berdasarkan pengujian statistik yang telah dilakukan menunjukkan CAR memiliki pengaruh positif terhadap Profitabilitas pada Perusahaan Bank Umum Syariah di Indonesia Periode 2017-2019. CAR digunakan untuk mengukur kecukupan modal yang dimiliki bank untuk menunjang aktiva yang mengandung atau menghasilkan risiko, artinya bank mampu menutupi risiko dengan modal yang dimiliki dan bank tidak mengalami kesulitan dalam kegiatan operasionalnya sehingga bank mampu meningkatkan profitabilitasnya.

Penelitian ini sejalan dengan penelitian yang telah dilakukan oleh Yusuf (2017), (Astohar, 2017) dan (Izzah et al., 2019), (Izzah et al., 2019) bahwa CAR berpengaruh positif terhadap profitabilitas. Penelitian ini menunjukkan adanya pengaruh positif dan signifikan antara CAR dan ROA yang artinya semakin besar CAR maka semakin besar pula ROA pada Bank Umum Syariah. Semakin tinggi CAR yang dicapai oleh bank menunjukkan kinerja bank semakin baik, sehingga pendapatan laba bank semakin meningkat. Hal ini disebabkan karena bank mampu menyalurkan dana atau modal yang dimilikinya dengan baik, dan karena dengan modal yang besar dan kinerja yang baik akan menimbulkan kepercayaan bagi masyarakat dan manajemen bank sangat leluasa dalam menempatkan dananya ke dalam aktivitas investasi yang menguntungkan.

\section{Pengaruh Non Performing Financing (NPF) Terhadap Profitabilitas}

Berdasarkan pengujian statistik yang telah dilakukan menunjukkan jika Non Performing Financing (NPF) tidak memiliki pengaruh terhadap Profitabilitas pada Perusahaan Bank Umum Syariah di Indonesia Periode 2017-2019. Setiap peningkatan atau penurunan variabel NPF tidak mempengaruhi profitabilitas (ROA) pada Perusahaan Bank Umum Syariah di Indonesia. Hal ini 
menunjukkan bahwa bank akan tetap memperoleh keuntungan dengan aset yang dimilikinya walaupun NPF yang dimiliki bank tersebut mengalami peningkatan ataupun penurunan. Dikarenakan pengaruh yang signifikan dari NPF terhadap ROA berkaitan langsung dengan penentuan tingkat kemacetan pembiayaan yang diberikan oleh sebuah bank.

Penelitian ini mendukung penelitian yang dilakukan oleh Yusuf (2017) dan Karim \& Hanafia (2020) yang menyatakan bahwa NPF tidak berpengaruh terhadap profitabilitas. Hal ini karena rata-rata NPF bank umum syariah di Indonesia di bawah angka standar BI yaitu sebesar 5\% sehingga NPF bank syariah tidak berpengaruh terhadap profitabilitas. Non Performing Financing (NPF) merupakan rasio yang dipergunakan untuk mengukur risiko terhadap kredit yang disalurkan dengan membandingkan kredit macet dengan jumlah kredit yang disalurkan. NPF adalah rasio yang digunakan untuk mengetahui pembiayaan bermasalah yang ditanggung oleh perbankan berdasarkan total pembiayaan yang telah disalurkan perbankan. Semakin tinggi NPF maka semakin kecil pula perubahan labanya. Hal ini dikarenakan pendapatan yang diterima bank akan berkurang dan biaya untuk pencadangan penghapusan piutang akan bertambah yang mengakibatkan laba menjadi menurun atau rugi menjadi naik.

\section{KESIMPULAN}

Berdasarkan analisis dan pembahasan hasil pengujian hipotesis dapat diajukan beberapa kesimpulan penting yang merupakan jawaban dari permasalahan yang dibahas dalam penelitian ini yaitu: (1) Financing to Deposit Ratio (FDR) tidak berpengaruh terhadap Profitabilitas pada Perusahaan Bank Umum Syariah di Indonesia Periode 2017-2019. Setiap peningkatan atau penurunan FDR tidak akan mempengaruhi naik turunnya ROA. (2) Capital Adequacy Ratio (CAR) berpengaruh positif terhadap Profitabilitas pada Perusahaan Bank Umum Syariah di Indonesia Periode 2017-2019. Setiap peningkatan CAR sebesar 1\% maka akan meningkatkan profitabilitas (ROA) sebesar 0.08 (8\%) dengan catatan variabel lain dianggap tetap. (3) Variabel Non Performing Financing (NPF) tidak berpengaruh terhadap Profitabilitas pada Perusahaan Bank Umum Syariah di Indonesia Periode 2017-2019. Setiap peningkatan atau penurunan variabel NPF tidak mempengaruhi profitabilitas pada Perusahaan Bank Umum Syariah di Indonesia.

\section{UCAPAN TERIMA KASIH}

Terima kasih Kepada Ketua STIE KBP, Ketua Prodi Akuntansi dan Lembaga P3M yang telah mensuport kegiatan penelitian yang kami jalani.

\section{REFERENSI}

Aldiansyah, T. (2018). Pengaruh Inflasi, BI Rate, NPF, Dan BOPO Terhadap Profitabilitas Bank Umum Syariah Di Indonesia. 6(1), 133-153.

Almunawwaroh, M., \& Marliana, R. (2018). Pengaruh CAR, NPF Dan FDR Terhadap Profitabilitas Bank Syariah Di Indonesia. 2(1), 1-18.

Astohar, A. (2017). PENGARUH CAPITAL ADEQUACY RATIO (CAR) DAN FINANCING TO DEPOSIT RATIO TERHADAP PROFITABILITAS PERBANKAN SYARIAH DI INDONESIA DENGAN INFLASI SEBAGAI VARIABEL PEMODERASI. Among Makarti, 9(2). Https://Doi.Org/10.52353/Ama.V9i2.138

Hanafia, F., \& Karim, A. (2020). Analisis CAR, BOPO, NPF, FDR, NOM, Dan DPK Terhadap Profitabilitas (ROA) Pada Bank Syari'ah Di Indonesia. Target: Jurnal Manajemen Bisnis, 2(1), 36-46. Https://Doi.Org/10.30812/Target.V2i1.697

Hanafiah, I., \& Sari, D. (2016). Analisis Pengaruh CAR, Kualitas Aset Produktif, Kualitas Manajemen, BOPO Dan Likuiditas Terhadap Profitabilitas (Studi Kasus Perusahaan Perbankan Yang Terdaftar Di BEI Tahun 2012-2016). (Septiadi 2014).

Hidayat, M. A., \& Meiranto, W. (2018). Prediksi Financial Distress Perusahaan Manufaktur Di Indonesia. Diponerogo Journal Of Accounting, 4(1), 24-51.

Izzah, R. N., Kosim, A. M., \& Gustiawati, S. (2019). Pengaruh Non Performing Financing 
Dan Capital Adequacy Ratio Terhadap Profitabilitas. Al Maal: Journal Of Islamic Economics And Banking, 1(1), 18. Https://Doi.Org/10.31000/Almaal.V1i1.1756

Khoirunnisa, H. M., Rodhiyah, \& Saryadi. (2016). Pengaruh Capital Adequacy Ratio (CAR), Loan To Deposit Ratio (LDR) Dan BOPO Terhadap Profitabiliitas (ROA Dan $R O E)$.

Mansuri. (2016). Modul Praktikum Eviews. In Eviews. Jakarta.

Marlina, M., \& Rivandi, M. (2020). Analisis Free Cash Flow, Profitabilitas, Deviden Dan Ukuran Perusahaan Terhadap Leverage Perusahaan Dengan Invesment Opportunity Set Sebagai Variabel Moderating Pada Sektor Trade, Service \& Invesment Yang Terdaftar Pada Bei. Jurnal Pundi, 3(3), 171. Https://Doi.Org/10.31575/Jp.V3i3.187

Munir, M. (2018). Analisis Pengaruh CAR, NPF,FDR Dan Inflasi Terhadap Profitabilitas Perbankan Syariah Di Indonesia. 1, 89-98.

Pinasti, W. F., \& Mustikawati, R. I. (2018). Pengaruh CAR, BOPO, NPL, NIM Dan LDR Terhadap Profitabilitas Bank Umum Periode 2011-2015. 7(1). Https://Doi.Org/10.21831/Nominal.V7i1.19365

Prabowo, R., \& Sutanto, A. (2019). Analisis Pengaruh Struktur Modal , Dan Likuiditas Terhadap Profitabilitas Pada Perusahaan Sektor Otomotif Di Indonesia. 10(1), 1-11.

Prasetiono, F. A. (2016). Pengaruh CAR , FDR , NPF , Dan BOPO Terhadap Profitabilitas (Studi Empiris Pada Bank Umum Syariah Di Indonesia Periode Tahun 2009-2013 ). Diponegoro Journal Of Management, 5(6), 1-10.

Purwanto, E. A., \& Sulistyastuti, D. R. (2017). Metode Penelitian Kuantitatif. Gava Media. Rivandi, M. (2020). Pengaruh Struktur Kepemilikan Terhadap Pengungkapan Corporate Social Responsibility. Akuntabilitas, 13(November), 205-220. Https://Doi.Org/10.15408/Akt.V13i2.17336

Rivandi, M., \& Septiano, R. (2021). PENGARUH INTELLECTUAL CAPITAL DISCLOSURE DAN. Jurnal Akuntansi Trisakti, 8(1), 123-136. Https://Doi.Org/Http://Dx.Doi.Org/10.25105/Jat.V8i1.7631

Sugiyono. (2017). Metode Penelitian Bisnis. Bandung: Alfabeta.

Syakhrun, M. (2019). Pengaruh CAR, BOPO, NPF Dan FDR Terhadap Profitabilitas Pada Bank Umum Syariah Di Indonesia. 2, 1-10.

Yusuf, M. (2017). Dampak Indikator Rasio Keuangan Terhadap Profitabilitas Bank Umum Syariah Di Indonesia. 13, 141-151. 